Bartın Üniversitesi İktisadi ve İdari Bilimler Fakültesi Dergisi, 2021, Cilt 12, Sayı 23

Bartın University Journal of Faculty of Economics and Administrative Sciences,

2021, Volume 12, Issue 23

E-ISSN: 2148-2497

http://iibfdergi.bartin.edu.tr/

https://dergipark.org.tr/tr/pub/bartiniibf

Araştırma Makalesi, Gönderim Tarihi: 12.03.2021; Kabul Tarihi: 22.05.2021

\title{
Does Agricultural Support Policy Affect Crop Production in Turkey?
}

\author{
Doç. Dr. Şerif CANBAY \\ Department of Economics, Düzce University, Akçakoca Bey Faculty of Political Sciences, \\ canbay.serif@gmail.com, Orcid ID: 0000-0001-6141-7510
}

\begin{abstract}
One of the most basic requirements of humanity is the need for nutrition. Therefore, the demand for food products that do not have a substitute for human life is quite heavy. To this end, the agricultural sector becomes prominent to meet the need for nutrition but puts economic units in a great search. In this context, the agricultural sector is an important dynamic of the country's economies. This study seeks to answer how support and incentives for the agricultural sector affect agricultural crop production. In this context, the ARDL bounds test with a structural break was conducted using Turkey's 1995-2018 data to determine the effects of agricultural supports on agricultural crop production. According to the analysis results, it was found out that agricultural supports in Turkey positively affect agricultural crop production in both the short and long term. Keywords: Agricultural support policy, crop production, agricultural sector, economic growth, ARDL bound test
\end{abstract}

JEL Sinıflandırması: O13, E01, C22

\section{Türkiye'deki Tarım Destek Politikaları Bitkisel Üretimi Etkiliyor Mu?}

\author{
Öz
}

İnsanoğlunun en temel gereksinimlerinin başında beslenme ihtiyacı bulunmaktadır. Bundan dolayı insanoğlunun hayatını sürdürebilmesi için ikamesi bulunmayan gıda ürünlerine yönelik talep oldukça yoğundur. $\mathrm{Bu}$ noktada beslenme ihtiyacinın karşılanması için tarım sektörü ön plana çıkmakla birlikte bu ihtiyaç ekonomik birimleri büyük bir arayış içerisine sokmaktadır. Bu bağlamda tarım sektörü ülke ekonomilerinin önemli bir dinamiği durumundadır. Bu çalışmada tarım sektörüne yönelik destek ve teşviklerin bitkisel üretimi nasıl etkilediği sorusuna yanıt aranmaktadır. Bu kapsamda Türkiye'nin 1995-2018 dönemi verileri ile tarım sektörüne yönelik desteklerin bitkisel üretim üzerindeki etkilerini tespit etmek maksadıyla yapısal kırılmalı ARDL sınır testi yapılmıştır. Analiz sonuçlarına göre gerek kısa gerekse de uzun dönemde Türkiye'de tarımsal desteklerin bitkisel üretimi pozitif yönde etkilediği bulgularına ulaşılmıştır.

Anahtar Kelimeler: Tarımsal destek politikaları, bitkisel üretim, tarım sektörü, iktisadi büyüme, ARDL bound test

JEL Classification: O13, E01, C22

APA: Canbay, Ş. (2021). Does Agricultural Support Policy Affect Crop Production in Turkey?. Bartın University Journal of Faculty of Economics and Administrative Sciences, 12 (23), 130-140.

APA: Canbay, Ş. (2021). Türkiye'deki Tarım Destek Politikaları Bitkisel Üretimi Etkiliyor Mu?. Bartın Üniversitesi İktisadi ve İdari Bilimler Fakültesi Dergisi, 12 (23), 130-140. 


\section{Introduction}

Nutrition is the most basic requirement that people need to maintain their lives. In this context, economic units are making great efforts to meet this need, which humanity needs the most and cannot be postponed. One of the main reasons for this effort is that the agricultural sector has an important place for macroeconomic performance indicators. At the top of these performance indicators is the contribution of the agricultural sector to employment. Especially for developing countries, this sector is an important employment source (Gollin et al., 2011:1). On the other hand, the agricultural sector also has a significant weight on inflation. This effect can have inflationary outcomes when agricultural products in high demand are not met with sufficient supply.

Agricultural activities without substitutes can have positive or negative effects on the balance of payments in terms of being subject to foreign trade and having a positive effect on poverty reduction, regional development, and economic growth (Doğan et al., 2015; Wickramasinghe, 2017). An import-based agricultural policy leads to the export of existing capital. On the other hand, an agricultural policy based on imports is also a source of trouble for food security in the event of a political crisis on the international platform. Besides, seeds developed in laboratories and food obtained from them to get more efficiency are a serious threat to human health. Therefore, organic agriculture, a sustainable agriculture system, has become widespread globally and started to be subject to international markets (Demiryürek, 2011: 27). For all these reasons that cannot be ignored, incentives, support, and subsidies for the agricultural sector, which have an important place in economies, are of great significance.

According to Vozarova and Kotulic (2016), agricultural incentives play an important role in developing the agricultural sector and the increase of foreign agricultural trade. Kumbhakar and Lien (2010) suggest that innovative agricultural supports will increase crop productivity together with the incentives to be introduced to the agricultural sector. There are few studies in the literature on how support and subsidies for the agricultural sector affect agricultural production or productivity. Hennessy (1998), Skuras et al. (2006), McCloud and Kumbhakar (2008), Gu (2014), Işık and Bilgin (2016), Vozarova and Kotilic (2016), and Akyol (2018) found that support for the agricultural sector increased agricultural crop productivity. Yildiz (2017) obtained the findings of bidirectional causality between variables. Roe et al. (2002) and Şaşmaz and Özel (2019) could not find a statistically significant relationship between the variables. Bezlepkina and Lansink (2006) and Nastis et al. (2012), on the other hand, found that agricultural supports reduced agricultural crop productivity in the findings of their studies. The findings of studies on the subject, which are limited in the literature, reveal different results. 
This study explores how agricultural support and incentives affect crop productivity using Turkey's 1995-2018 data. In this context, the bound test based on the Autoregressive Delay Distributed Model (ARDL) developed by Pesaran et al. (2001) was used. The study includes data and model, and then methods and findings, respectively. Finally, in the conclusion chapter, some policy recommendations are presented based on the findings.

\section{Data and Model}

This study aimed to investigate the impact of agricultural support on crop production using data from 1995 to 2017 in Turkey. Data on the variables contained in the model are taken from the official website of the Organization for Economic Cooperation and Development (OECD). The crop production (CP) (OECD, 2021a) in the model is presented for wheat, maize, rice, and soybean. Crop production is measured in thousand hectares. The other variable of agricultural support (AS) (OECD, 2021b) is defined as government practices that increase producers or consumers' income or reduce their costs. Irrespective of their objectives and economic impacts, the definition of agricultural support involves the annual monetary value of gross transfers to agriculture from consumers and taxpayers resulting from government policies based on agricultural support. Agricultural support is expressed in terms of million USD.

It is useful to examine the graphs of the variables before the analysis. In time series analysis, the graphs of the variables in the model can provide explanatory information on issues such as refraction, trend, and seasonality. The graphics of the variables drawn in this context are included in Figure 1.

Figure 1: Graphs of variables

$\mathrm{CP}$

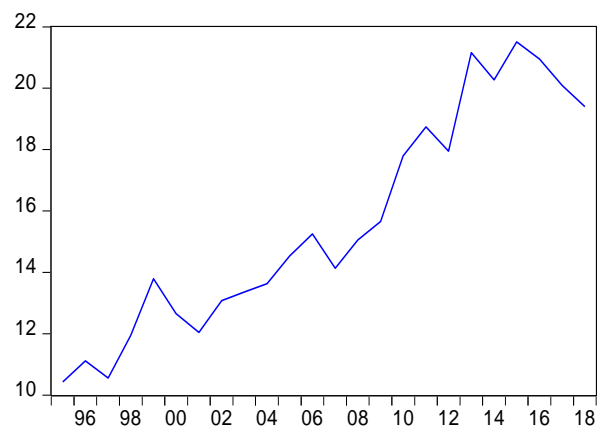

AS

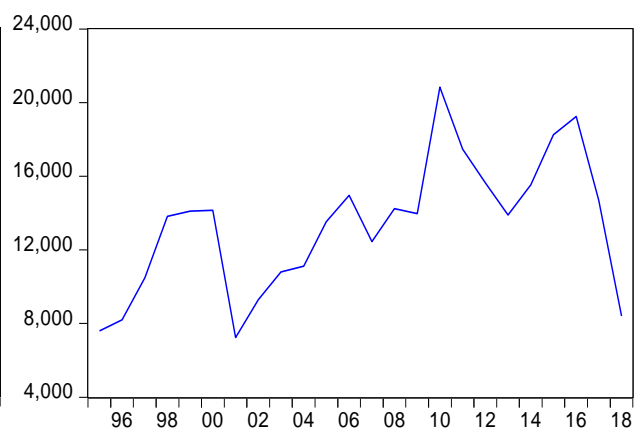


The presence of breaks in the graphs of the variables is noteworthy. Detecting these breaks and including them in the model leads to more accurate results.

The study is based on model (1) as follows:

$$
C P_{t}=\beta_{0}+\beta_{1} A S_{t}+\alpha_{i} \text { Breaks }+u_{t}
$$

In model (1), the dependent variable is CP and the independent variable is AS. In terms of representing the breaks seen in the graphs of the variables in Figure 1, the Breaks variable shows the dummy variables belonging to the break dates determined in the ADF unit root test with a single break and $\boldsymbol{\alpha}_{\boldsymbol{i}}$ represents the coefficient of the dummy variables. The index $t$ is the time series of the variables belonging to the variables, $\boldsymbol{\beta}_{\mathbf{0}}$ is the constant term coefficient of the model, $\boldsymbol{\beta}_{\mathbf{1}}$ is the slope coefficient of the model, and ut is the error term of the model.

\section{Methodology and Findings}

In this study, the stationarity levels of variables are firstly examined with the ADF unit root test with a single break. Then, short- and long-term relationships between variables are investigated with ARDL bound testing after the unit root test with a single break.

Table 1 contains the results of the ADF unit root test with a single break for the variables.

Table 1: Single-Break ADF Unit Root Test *

\begin{tabular}{|l|c|c|c|}
\hline \multicolumn{1}{|c|}{ Variable } & t-Statistic & Probability & Date of break \\
\hline $\mathbf{C P}$ & -3.414 & 0.851 & 2012 \\
\hline $\boldsymbol{\Delta C P}$ & $\mathbf{- 7 . 3 0 9 * *}$ & $\mathbf{0 . 0 0 1}$ & $\mathbf{2 0 1 2}$ \\
\hline $\mathbf{A S}$ & -4.311 & 0.331 & 2009 \\
\hline $\boldsymbol{\Delta A S}$ & $\mathbf{- 5 . 1 7 9} * *$ & $\mathbf{0 . 0 4 9}$ & $\mathbf{2 0 0 5}$ \\
\hline
\end{tabular}

* The unit root test was performed in constant and trend models by taking into account the breaks.

** Expresses stationarity according to $\% 5$ level of significance. 
According to the results of the ADF unit root test with a single break, when the first degree I(1) differences of the variables are taken, they become stable at the 5\% statistical significance level. On the other hand, it was determined that there were breaks for the CP variable in 2012 and the AS variable in 2005 and 2009.

ARDL bound test is a test that provides the opportunity to examine the long-term relationships between variables and the long-term relationships between stationary variables at different levels. ARDL model of the study is as seen in the model (2).

$\boldsymbol{C} \boldsymbol{P}_{t}=\theta_{0}+\sum_{i=1}^{p} \Theta_{1 i} \boldsymbol{C P}_{t-i}+\sum_{i=0}^{r} \Theta_{2 i} A S_{t-i}+\alpha_{i}$ Breaks $+\boldsymbol{e}_{t}$

The $\Theta s$ in the model (2) indicate the coefficient matrix of the independent variables. The $\mathrm{p}$ and $\mathrm{r}$ symbols show the different lag numbers of the variables, $\mathrm{i}$ shows the lag number, and et is the error term of the model. Lag numbers were determined by the Akaike Information Criteria (AIC). The dependent variable of the study was added as an exogenous variable to the 2012 ARDL model, which is the break date determined for CP.

According to the analysis results, it was determined that the ARDL $(3,3)$ model is the appropriate model. Some descriptive tests are required to test the suitability of the ARDL $(3,3)$ model. The results of these tests are shown in Table 2.

Table 2: Descriptive Statistics

\begin{tabular}{|l|c|c|}
\hline Tests & Calculated Statistics & Prob. \\
\hline Breusch-Godfrey Autocorrelation & 0.524 & 0.769 \\
\hline Breusch-Pagan-Godfrey Test & 7.046 & 0.531 \\
\hline Jargue-Bera Test of Normality & 1.527 & 0.466 \\
\hline Ramsey RESET & 0.335 & 0.574 \\
\hline
\end{tabular}


It was determined that there are no autocorrelation and variance problems, and the error terms are normally distributed in the descriptive statistics for the $\operatorname{ARDL}(3,3)$ model. Finally, CUSUM and CUSUM-SQ analysis need to be conducted to determine whether the current coefficients are stable or not. The results of the CUSUM and CUSUM-SQ analyzes are shown in Figure 2.

\section{Figure 2: CUSUM and CUSUMQ Results}

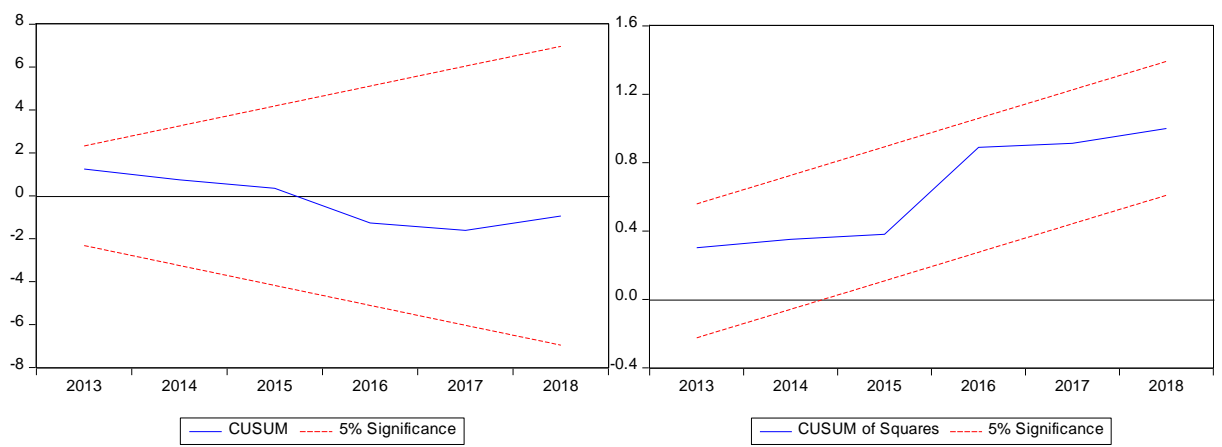

For the ARDL $(3,3)$ model, it is seen that CUSUM and CUSUM-SQ are within $5 \%$ confidence intervals. This result indicates that the coefficients obtained are stable. After these results, the results of the $\operatorname{ARDL}(3,3)$ model are presented in Table 3.

Table 3: ARDL (3,3) Model Prediction

\begin{tabular}{|c|c|c|c|c|}
\hline Variable & Coefficient & Stand. Error & t-Statistics & Prob. \\
\hline CP(-1) & 0.092292 & 0.244891 & 0.376871 & 0.7128 \\
\hline CP(-2) & 0.2132 & 0.217998 & 0.977988 & 0.3474 \\
\hline CP(-3) & 0.200728 & 0.207127 & 0.969105 & 0.3516 \\
\hline AS & $\mathbf{0 . 0 0 0 3 1 3 *}$ & $\mathbf{7 . 4 6 E - 0 5}$ & $\mathbf{4 . 1 8 8 1 8 6}$ & $\mathbf{0 . 0 0 1 3}$ \\
\hline AS(-1) & $6.91 E-05$ & 0.000105 & 0.660161 & 0.5216 \\
\hline AS(-2) & -0.000122 & $9.43 E-05$ & -1.295485 & 0.2195 \\
\hline AS(-3) & $\mathbf{0 . 0 0 0 2 4 1 *}$ & $\mathbf{8 . 8 7 E - 0 5}$ & $\mathbf{2 . 7 2 2 8 7 2}$ & $\mathbf{0 . 0 1 8 5}$ \\
\hline$\Delta 2012$ & 1.308668 & 0.998948 & 1.310047 & 0.2147 \\
\hline C & 1.266429 & 1.853424 & 0.683291 & 0.5074 \\
\hline
\end{tabular}

* Expresses significance according to $5 \%$ level of significance. 
The equation obtained for the bound test is as in equation (3) below:

$$
\Delta C P_{t}=\theta_{0}+\sum_{i=1}^{p} \theta_{1 i} \Delta C P_{t-i}+\sum_{i=0}^{r} \theta_{2 i} \Delta A S_{t-i}+\theta_{3} C P_{t-i}+\theta_{4} A S_{t-i}+\alpha_{i} \text { Breaks }+e_{1 t} \text { (3) }
$$

Besides, the hypotheses of the test are listed below.

$$
\begin{aligned}
& \mathrm{H}_{0}: \theta 3=\theta 4=0 \text { (no cointegration), } \\
& \mathrm{H}_{1}: \theta 3 \neq \theta 4 \neq 0 \text { (cointegration). }
\end{aligned}
$$

In the hypotheses, the statistical value of the bound test is determined by testing whether the coefficients of $\theta 3=\theta 4=0$ expressed in the model with Wald F statistics are equal to zero simultaneously. This statistical value determined for the hypotheses is compared with the lower limit I(0) and upper limit I(1) values specified in the article of Pesaran et. al. (2001: 300). If the calculated value is greater than the critical value of $\mathrm{I}(1), \mathrm{H}_{0}$ is rejected. In other words, there are long-term relationships between variables.

Table 4: ARDL Bounds Testing Results

\begin{tabular}{|c|c|c|c|}
\hline $\mathrm{K}$ & F-Statistic & \multicolumn{2}{|c|}{$1 \%$ Critical Values } \\
\hline \multirow{2}{*}{1} & \multirow{2}{*}{$6.028^{*}$} & $\mathrm{I}(0)$ & $\mathrm{I}(1)$ \\
\cline { 3 - 4 } & & 4.94 & 5.58 \\
\hline
\end{tabular}

The bound test findings shown in Table 4 indicate that the $\mathrm{F}$ statistic value is greater than the critical values, that is, the $\mathrm{H}_{0}$ hypothesis is rejected. Therefore, this situation shows that the AS variable affects the CP variable in the long term. On the other hand, it should be observed that the error correction mechanism works and what kind of interaction there is between variables in the long and short term should be determined. The error correction mechanism is tested with model (4).

$\Delta C P_{t}=\theta_{0}+\sum_{i=1}^{m} \theta_{1 i} \Delta C P_{t-i}+\sum_{i=0}^{n} \theta_{2 i} \Delta A S_{t-i}+\theta_{3} E C M_{t-1}+e_{2 t}$

The fact that the coefficient of $\operatorname{ECM}(-1)$ in the model (4) is between 0 and -1 and statistically significant indicates that the imbalances between the variables improve in the short term. Table 5 shows the short- and long-term results of the error correction model. 
Table 5: Short-Term and Long-Term Coefficients

\begin{tabular}{|l|c|c|c|c|}
\hline \multicolumn{5}{|c|}{ Short-Term Coefficients and Error Correction Model } \\
\hline Variable & Coefficient & Standard Error & t-Statistics & Prob. \\
\hline C & 1.266 & 1.853 & 0.683 & 0.507 \\
\hline CP(-1) & -0.493 & 0.182 & -2.704 & 0.019 \\
\hline AS(-1) & $\mathbf{0 . 0 0 1 *}$ & $\mathbf{0 . 0 0 1}$ & $\mathbf{3 . 0 8 8}$ & $\mathbf{0 . 0 0 9}$ \\
\hline$\Delta(\mathrm{CP}(-1))$ & -0.413 & 0.210 & -1.963 & 0.073 \\
\hline$\Delta(\mathrm{CP}(-2))$ & -0.200 & 0.207 & -0.969 & 0.352 \\
\hline$\Delta(\mathrm{AS})$ & $\mathbf{0 . 0 0 1 *}$ & $\mathbf{7 . 4 6 E - 0 5}$ & $\mathbf{4 . 1 8 8}$ & $\mathbf{0 . 0 0 1}$ \\
\hline$\Delta(\mathrm{AS}(-1))$ & -0.001 & 0.001 & -1.101 & 0.293 \\
\hline$\Delta(\mathrm{AS}(-2))$ & $\mathbf{- 0 . 0 0 1 *}$ & $\mathbf{8 . 8 7 E - 0 5}$ & $\mathbf{- 2 . 7 2 2}$ & $\mathbf{0 . 0 1 9}$ \\
\hline$\Delta 2012$ & 1.308 & 0.998 & 1.3100 & 0.215 \\
\hline ECM(-1) & $\mathbf{- 0 . 4 9 3}$ & $\mathbf{0 . 1 0 7}$ & $\mathbf{- 4 . 5 9 3}$ & $\mathbf{0 . 0 0 1}$ \\
\hline \multicolumn{5}{|c|}{ Long-Term Coefficients } \\
\hline Variable & Coefficient & Standard Error & t-Statistics & Prob. \\
\hline AS & $\mathbf{0 . 0 0 1 *}$ & $\mathbf{0 . 0 0 1}$ & $\mathbf{3 . 5 4 2}$ & $\mathbf{0 . 0 0 4}$ \\
\hline C & 2.564 & 3.265 & 0.785 & 0.448 \\
\hline
\end{tabular}

* Expresses significance according to 5\% level of significance

According to Table 5, a statistically significant and positive relationship was found between the AS and CP variables both in the short and long term. Additionally, $\operatorname{ECM}(-1)$ coefficient is between 0 and -1 , and it is seen to be statistically significant. This means that the error correction mechanism of the model works correctly. This means that deviations in the short term stabilize in the long term. 


\section{Conclusion}

Turkey's 1995-2018 data were used in this study, which seeks to answer how agricultural support affects crop production. The ARDL limit test was used in the study. According to the results, agricultural support positively affects crop production both in the short and long term in Turkey.

The effects of the agricultural sector on macroeconomic performance indicators are an issue that governments should not ignore. In particular, the way to transfer the effects on employment, growth, inflation, and current account deficit to indicators positively is through the support and incentives to be applied to the sector. According to the World Bank (2021) data, Turkey's agricultural sector's share of GDP was $17.5 \%$ in 1990 , it declined to $6.4 \%$ in 2019 . During this period, the share of the manufacturing industry increased from $17.32 \%$ to $27.19 \%$. The share of Turkey's agricultural support in GDP was $4.36 \%$ in 1990 , and this share decreased to $1.06 \%$ as of 2019 . OECD countries' average agricultural support in 2019 was 281.081 million US dollars, while this support was 7.223 million US dollars in Turkey, well below that of OECD countries (OECD, 2021b). It can be stated that the most important reason for this change in this process is due to the policies implemented by governments. These data are an indicator of the neglect of the agricultural sector in Turkey, although incentives for the sector increase crop productivity.

The existence of import-dependent manufacturing industry in Turkey deepens the current account deficit problem, while the agricultural sector is a sector with the potential to eliminate this problem. Although it is important to support all sectors of the whole economy, it is also important to support the agricultural sector. Globalized economies' resistance to external shocks can be mitigated by supporting sectors with domestic opportunities, such as the agricultural sector. On the other hand, in addition to being a solution to Turkey's unemployment problem, it can lead to economic growth by increasing output. Consequently, the surplus of the agricultural products produced for domestic markets can be exported, and the current account deficit problem can be eliminated with foreign exchange inflow to the country.

The findings of the study reveal the importance of support for the agricultural sector. Therefore, researchers should continue new studies in which different methods and different variables are included in the model. Such studies will be important supportive studies for the future of the industry.

\section{References}

Akyol, M. (2018). An Examination of the Relationship Between Agricultural Incentives and Agricultural Added Value: Panel Simulated Equations System Analysis for New Industrialized Countries, The Journal of International Scientific Researches, 3(3), 226-236. 
Bezlepkina, I. V. \& Lansink, A. O. (2006). Impact of Debts and Subsidies on Agricultural Production: Farm-Data Evidence, Quarterly Journal of International Agriculture, 45(1), 7-34.

Demiryürek, K. (2011). The Concept of Organic Agriculture and Current Status of in the World and Turkey, GOÜ, Ziraat Fakültesi Dergisi, 28(1), 27-36.

Doğan, Z., Arslan, S. \& Berkman, A. N. (2015). Development and Problems of Agricultural Sector in Turkey: A Historical Outlook, Niğde Üniversitesi İ̈BF Dergisi, 8(1), 29-41.

Gollin, D., Lagakos, D. \& Waugh, M.E. (2011). The Agricultural Productivity Gap in Developing Countries, International Growth Center Working Paper.

Gu, Z. (2014). Evolution of Post-War Agricultural Support Policiesin China's Taiwan, Asian Agricultural Research, 6(11), 58-61.

Hennessy, D. A. (1998). The production effects of agricultural income support polices under uncertainty, American Journal of Agricultural Economics, 80(1), 46-57.

Işık, H. B. \& Bilgin, O. (2016). The effects of agricultural support policies on agricultural production: The case of Turkey, RSEP International Conferences on Social Issuesand Economic Studies, 2nd Multidisciplinary Conference Madrid SPAIN 2-4 November, 111-119.

Kumbhakar, S. C. \& Lien, G. (2010). Impact of Subsidies on Farm Productivity and Efficiency, The Economic Impact of Public Support to Agriculture, Studies in Productivity and Efficiency 7, ed. by V. Eldon Ball, Roberto Fanfani, Luciano Gutierrez, Springer, 109-124.

McCloud, N. \& Kumbhakar, S. C. (2008). Do subsidies drive productivity? A crosscountry analysis of Nordic dairy farms, In: Bayesian econometrics. Emerald Group Publishing Limited, ed. by Siddhartha Chib, William Griffiths, Gary Koop, Dek Terrell. Emerald Group Publishing Limited, 23, 245-274.

Nastis, S. A., Papanagiotou, E. \& Zamanidis, S. (2012). Productive Efficiency of Subsidized Organic Alfalfa Farms, Journal of Agricultural and Resource Economics, 37(2), 280-288.

OECD (2021), Agricultural Support (indicator). doi: 10.1787/6ea85c58-en [Accessed on 08 March 2021]

OECD (2021), Crop Production (indicator). doi: 10.1787/49a4e677-en [Accessed on 08 March 2021] 
Pesaran, M. H., Shin, Y. \& Smith, R. J. (2001). Bounds Testing Approaches to the Analysis of Level Relationships, Journal of Applied Econometrics, 16(3). 289326.

Roe, T., Somwaru, A. \& Diao, X. (2002). Do Direct Payments Have Intertemporal Effects on U.S.'s Agriculture? in Government Policy and Farmland Markets: The Maintenance of Farmer Wealth, Trade and Macroeconomics Division International Food Policy Research Institute, ed. by Charles B. Moss and Andrew Schmitz, Iowa State Press, 115-140.

Skuras, D., Kostas, T., Dimara, E. \& Tzelepis, D. (2006). The Effects of Regional Capital Subsidies on Productivity Growth: A Case Study of The Greek Food and Beverage Manufacturing Industry, Journal of Regional Science, 46, 355-381.

Şaşmaz, M.Ü. \& Özel, Ö. (2019). Effect of Agricultural Incentives on the Development of Agricultural Sector: Example of Turkey, Dumlupınar University Journal of Social Sciences, 61, 50-65.

World Bank (2021). Agriculture, Value Added (\% of GDP) Database, https://databank. worldbank.org/reports.aspx? source=2\&series=NV.AGR.TOTL. ZS\&country=[ Accessed on 10.02.2021]

Vozarova, I. K. \& Kotulic, R. (2016). Quantification of the Effect of Subsidies on the Production Performance of the Slovak Agriculture, Procedia Economics and Finance, 39, 298-304.

Wickramasinghe, G.A. U. (2017). Fostering Productivity in the Rural and Agricultural Sector for Inclusive Growth in Asia and the Pacific, Asia-Pacific Development Journal, 24(2), 1-22.

Y1ld1z, F. (2017). The Effect of Agricultural Support Payments Made from the Central Government Budget on Agricultural Production in Turkey: The Period of 20062016, Sayıştay Dergisi, 104, 45-63. 